\section{High Tunnel and Grafting Effects on Organic Tomato Plant Growth and Yield in the Subtropics}

\author{
Craig J. Frey ${ }^{1}$, Xin Zhao $^{1}$, Jeffrey K. Brecht ${ }^{1}$, Dustin M. Huff ${ }^{1}$, \\ and Zachary E. Black ${ }^{1}$
}

ADDITIONAL INDEX WORDs. fruit cracking, fruit decay, hoop house, marketable yield, open field, Solanum lycopersicum, stink bug, unmarketable yield characteristics

SUMmary. Although grower interest in high tunnel tomato (Solanum lycopersicum) production has increased in recent years, systematic high tunnel research conducted in humid, subtropical regions has been limited. The potential of tomato grafting to mitigate biotic and abiotic stresses makes it complementary to high-value production systems in high tunnels. In this 2-year study, grafted vs. nongrafted organic tomato production in high tunnels and open fields was investigated to determine possible synergistic effects of these two technologies. In 2016, high tunnels resulted in a significant increase of total and marketable yields, by $43 \%$ and $87 \%$, respectively, over open field production. Grafting also significantly increased total and marketable yields over nongrafted plants by $34 \%$ and $42 \%$, respectively. Cultivar effects demonstrated greater benefits with the implementation of high tunnel and grafting technologies for 'Tribute' (a beefsteak-type tomato) than for 'Garden Gem' (a plum-type tomato), as the increase in marketable yield was 33\% greater for 'Tribute' in high tunnels and $45 \%$ greater for 'Tribute' with grafting. In 2017 , a delayed effective transplanting date and the lack of high tunnel summer season extension produced results that were generally cultivar specific. While grafting increased the total yield of both cultivars (by 18\%), marketable yield was increased by grafting only for 'Tribute' in high tunnels (by $42 \%$ ). Additionally, high tunnels improved marketable yield of 'Tribute' by $129 \%$ but had no effect on 'Garden Gem'. This demonstrated the consistent trend of the beefsteak-type tomato benefiting more from the combination of high tunnel and grafting technologies than the plum-type tomato. High tunnels reduced fruit decay and cracking by up to $71 \%$ compared with open field production. Stink bug (Pentatomidae) damage had the greatest impact on marketable yields each season, reaching $13 \%$ and $34 \%$ of total yields in 2016 and 2017, respectively, and was unaffected by high tunnel production or grafting. This study revealed the benefits of integrating high tunnel and grafting technologies for enhancing organic production of fresh-market tomato in the humid subtropics, and demonstrated more research is warranted to establish regional planting dates and further optimize this high-value cropping system. organic tomato sales rank second for organic vegetables, and Florida is the second largest producer in the country (USDA, 2017). The direct marketing sector has also grown rapidly, with $45 \%$ of U.S. organic farms selling directly to consumers, and over $60 \%$ in Florida (USDA, 2015a, 2015b). Yet productivity is a challenge for organic growers, and yield of organic tomato is estimated to be $20 \%$ less than conventional yields overall (Seufert et al., 2012).

Tomato production limitations in the humid subtropics are greater than in other regions due to frequent rainfall, prolonged dews, temperature extremes, and severe temperature fluxes (Frey et al., 2020; McAvoy and Ozores-Hampton, 2007). Insect and disease incidence may also be prolonged and severe because moderate winter temperatures may not initiate diapause for some pests or survival structures for some pathogens. High tunnel and grafting technologies may benefit both conventional and organic tomato growers in mitigating these biotic and abiotic factors and achieving high-quality fresh market tomato production in the subtropics. The beneficial impact may be greater for organic production systems for which management tools tend to be more limited and the effectiveness and longevity may be reduced.

Polyethylene-covered high tunnel structures, also called hoop houses, can offer a moderate level of environmental protection in crop production and facilitate season extension (Lamont, 2005, 2009). Tomato is the most commonly grown crop in high tunnels worldwide (Carey et al., 2009; Janke et al., 2017; Lamont, 2009). High tunnel adoption by Florida growers for horticultural crop production has increased dramatically since 2001 (Frey et al., 2020; Hochmuth and Toro, 2014), while high tunnel vegetable crop research in Florida is limited. publication 8 May 2020 .

Published online 30 June 2020.

${ }^{1}$ Horticultural Sciences Department, University of Florida, Gainesville, FL 32611

This work was supported by the Agriculture and Food Research Initiative Food Security Program grant no. 2014-68004-21824 and the Specialty Crop Research Initiative grant no. 2016-51181-25404 from the U.S. Department of Agriculture National Institute of Food and Agriculture. We appreciate the seed donation from Dr. Harry J. Klee and Sakata Seed America, Inc., for the tomato scion cultivars, and the statistical analysis advice provided by James Colee with the University of Florida, Institute of Food and Agricultural Sciences, Statistical Consulting Unit.

X.Z. is the corresponding author. E-mail: zxin@ufl. edu.

This is an open access article distributed under the CC BY-NC-ND license (https://creativecommons.org/ licenses/by-nc-nd/4.0/).

https://doi.org/10.21273/HORTTECH04610-20
$\mathrm{C}$ onventional tomato (Solanum lycopersicum) production in the United States has declined in recent years while growth of organic production has increased rapidly [U.S. Department of Agriculture (USDA), 2008, 2016, 2017]. U.S.

\begin{tabular}{llll}
\hline $\begin{array}{l}\text { Units } \\
\text { To convert U.S. to SI, } \\
\text { multiply by }\end{array}$ & U.S. unit & SI unit & $\begin{array}{l}\text { To convert SI to U.S., } \\
\text { multiply by }\end{array}$ \\
\hline 0.3048 & $\mathrm{ft}$ & $\mathrm{m}$ & 3.2808 \\
2.54 & inch $(\mathrm{es})$ & $\mathrm{cm}$ & 0.3937 \\
25.4 & inch $(\mathrm{es})$ & $\mathrm{mm}$ & 0.0394 \\
0.4536 & $\mathrm{lb}$ & $\mathrm{kg}$ & 2.2046 \\
1.1209 & $\mathrm{lb} / \mathrm{acre}$ & $\mathrm{kg} \cdot \mathrm{ha}^{-1}$ & 0.8922 \\
28.3495 & $\mathrm{oz}$ & $\mathrm{g}$ & 0.0353 \\
$\left({ }^{\circ} \mathrm{F}-32\right) \div 1.8$ & ${ }^{\circ} \mathrm{F}$ & ${ }^{\circ} \mathrm{C}$ & $\left({ }^{\circ} \mathrm{C} \times 1.8\right)+32$
\end{tabular}


Although reduction of leaf wetness and extension of harvest season may be the most significant benefits of high tunnels in the subtropics, high tunnels can also moderate drastic temperature fluctuations and croplimiting temperature extremes, thus reducing crop stress and increasing productivity (Frey et al., 2020; Jayalath et al., 2017; Rogers and Wszelaki, 2012). Biotic stress reduction has been reported in high tunnel tomato production, including foliar diseases such as early blight (Alternaria solani) and bacterial speck (Pseudomonas syringae pv. tomato), as well as some insect pests (Antignus et al., 1996; Healy et al., 2017; O'Connell et al., 2012; Waiganjo et al., 2013). The use of ultraviolet-absorbing plastics and the resultant rainwater protection may reduce the degradation or removal of pesticide residues and reduce nutrient leaching, increasing the pesticide efficacy and nutrient efficiency of the growing system (Leach et al., 2017).

High tunnel abiotic and biotic stress amelioration may improve tomato plant growth characteristics, including fruit size and number, and total and marketable yields (Carey et al., 2009; Healy et al., 2017; O'Connell et al., 2012). Enhanced aesthetic appeal of high tunnel tomatoes compared with open field fruit, including improved color and color uniformity, has also been reported (Talavera-Bianchi et al., 2010). These effects, along with season extension, may result in higher premium prices, particularly for direct market growers, while reducing the risk of losses compared with open field conditions (Blomgren and Frisch, 2007; O'Connell et al., 2012). Although substantial information is available from high tunnel trials in temperate regions, systematic research of high tunnel production is scarce in subtropical growing systems, where conducive environments lead to persistent disease and pest problems.

Grafting as a management tool has been increasingly used in tomato production in the United States, often targeting the suppression of diseases caused by soilborne pathogens such as Fusarium sp. and root-knot nematodes [RKN (Meloidogyne sp.)], which are widespread in the subtropics (Frey et al., 2020; Guan et al., 2012; King et al., 2008). Tomato grafting has the potential to increase crop vigor, as measured by an increase in stem diameter, leaf area, and aboveand below-ground biomass (Öztekin and Tüzel, 2017; Rahmatian et al., 2014). Tomato marketable and total yields, as well as average fruit weight, may increase compared with fruit from nongrafted plants (Barrett et al., 2012; Djidonou et al., 2013; Rahmatian et al., 2014; Rivard et al., 2012; Savvas et al., 2010). With appropriate rootstock selection, grafting may improve water- and nitrogen-use efficiency, enhance salinity tolerance, and reduce blossom end rot (BER), the most common preharvest tomato physiological disorder (Di Gioia et al., 2013; Djidonou et al., 2013; Fan et al., 2011; Krumbein and Schwarz, 2013). Although tomato grafting could potentially address many challenges faced by tomato growers in the subtropics, the high cost associated with the use of grafted plants demands production systems that maximize grafting benefits, such as by extending the harvest season and ameliorating detrimental microclimate effects.

This study was therefore designed to compare grafted and nongrafted organic tomato production in sideby-side open-field and high-tunnel systems. The objectives of this study were to determine high tunnel and grafting effects on plant growth characteristics and yield performance, including total and marketable yield components, and the characteristics that lead to unmarketability.

\section{Materials and methods}

Plant material. Organic tomato trials were carried out in the Spring seasons of 2016 and 2017 on USDA-certified organic land at the University of Florida Plant Science Research and Education Unit (PSREU) in Citra. 'Tribute' (Sakata Seed America, Morgan Hill, CA) and 'Garden Gem' (H.J. Klee, University of Florida, Gainesville) were used as tomato scions, with 'Multifort' (Paramount Seeds, Inc., Stuart, FL) as the rootstock. 'Tribute' is a hybrid determinate, round, slicing tomato with good heat-set ability and high resistance to alternaria stem canker (Alternaria alternata f. sp. lycopersici), fusarium wilt (Fusarium oxysporum f. sp. lycopersici race 1 and 2), and verticillium wilt (Verticillium dabliae race 1 ), and intermediate resistance to gray leaf spot (Stemphylium solani, Stemphylium lycopersici), Tomato spotted wilt virus (TSWV), and Tomato yellow leaf curl virus (TYLCV). 'Garden Gem' is a semideterminate, plum-type hybrid tomato that was bred for a flavor profile comparable to heirloom tomatoes (Zhu et al., 2017). 'Multifort' is a vigorous, interspecific hybrid tomato (S. lycopersicum $\times$ Solanum habrochaites) rootstock that provides high resistance to fusarium wilt and RKN. 'Tribute', 'Garden Gem', and 'Multifort' were seeded on 26 Jan. 2016 and 27 Jan. 2017 in the greenhouse, and seedlings were grafted on 18 Feb. 2016 and 23 Feb. 2017 using the splice method as described by Frey et al. (2020).

Field EXPERIMENTS. The soil texture at the field site consisted of $96.8 \%$ sand, $2 \%$ clay, and $1.2 \%$ silt. Field preparation, including compost application, tillage, bed formation, and preplant organic fertilizer application, was described in detail by Frey et al. (2020). Briefly, composted cow manure and organic fertilizer were applied to raised beds before planting. Fertilizer application rates were determined based on preplant soil test results, crop needs (Liu et al., 2016), and estimated seasonal nutrient availability of the compost and organic fertilizers used. Average total season applications of nitrogen $(\mathrm{N})$, phosphorous $(\mathrm{P})$, and potassium $(\mathrm{K})$ from compost and fertilizer applications were $210.2,25.4$, and $195.3 \mathrm{lb} / \mathrm{acre}$, respectively (Frey et al., 2020).

A split-split plot design with three replications was used as described by Frey et al. (2020). The whole plots included three, single-bay high tunnels, measuring $48 \mathrm{ft}$ (length) $\times 24 \mathrm{ft}($ width), and corresponding side-by-side open field plots. The whole plots were randomly arranged in three blocks with $24-\mathrm{ft}$ spacing between high tunnels and field plots, sufficient to avoid shading effects. Subplots consisted of 'Garden Gem' and 'Tribute' and sub-subplots included grafted and nongrafted plants. Each sub-subplot consisted of 28 plants across four beds, with one row per bed and plants spaced at $1.5 \mathrm{ft}$ within each bed and bed centers spaced at $6 \mathrm{ft}$. Seedlings of nongrafted and grafted 'Tribute' and 'Garden Gem' were transplanted into raised beds in a north-south orientation on 9 Mar. in both seasons and the 
tomato beds were hay-mulched after transplanting. A freeze event and herbicide contamination of compost necessitated a large amount of replanting during the first two weeks of the 2017 growing season, and the effective transplanting date for the 2017 season was therefore considered to be 23 Mar. (Frey et al., 2020). The compost herbicide contamination was determined to be aminopyralid, which has a half-life in soil of $34.5 \mathrm{~d}$ (Shaner, 2014). While plant symptom recovery occurred within 2 to 3 weeks of appearance, it is unknown what effect this might have had on plant growth. Symptom incidence was greater in the high tunnel than in the open field.

For early season growth, high tunnel sides were kept closed. Tunnel ends were closed when air temperatures were $<50{ }^{\circ} \mathrm{F}$, and all sides remained open when air temperatures were $>80$ ${ }^{\circ} \mathrm{F}$. For late-season growth, shadecloth (Aluminet I 40\% Greenhouse Shadecloth; Green-Tek, Inc., Dinuba, CA) was applied to the high tunnels as daily high temperatures in the open field were sustained above $90{ }^{\circ} \mathrm{F}$ (2 May 2016 and 17 Apr. 2017). The effects of high tunnel management on microclimate conditions were reported by Frey et al. (2020).

Plants were fertigated weekly with Aqua Power 5N-0.4P-0.8K liquid fish fertilizer (JH Biotech, Inc., Ventura, CA) and Big-K $0 \mathrm{~N}-0 \mathrm{P}-$ $41.5 \mathrm{~K}$ sulfate of potash (JH Biotech, Inc.) through the drip irrigation system at an adjustable rate based on plant stage (Frey et al., 2020; Liu et al., 2016). Tomatoes were trellised using the common, commercial Florida stake and weave method (Thaxton and Hochmuth, 2015).

Pest and disease management. Weekly field scouting was conducted to determine pesticide and fungicide applications and insect and tissue sampling was performed for diagnosis. Disease management practices and assessment of foliar diseases and RKN were detailed in Frey et al. (2020). Spinosad (Entrust SC Naturalyte Insect Control; Dow AgroSciences, Indianapolis, IN), Bacillus thuringiensis ssp. kurstaki strain ABTS-351 (DiPel DF Biological Insecticide; Valent BioSciences, Libertyville, IL), Chromobacterium subtsugae strain PRAA4- $1^{\mathrm{T}}$ (Grandevo; Marrone Bio Innovations, Davis, CA), and pyrethrins (PyGanic Crop
Protection EC 5.0 II; McLaughlin Gormley King Company, Minneapolis, MN) were used at labeled rates in rotation once or twice a week for pest management based on field scouting results.

Stink bugs have increasingly become a major pest in organic tomato production, as organic insecticides are largely ineffective (Kamminga et al., 2009; Morehead and Kuhar, 2017). In attempts to reduce stink bug populations in the tomato cash crop, sunflower (Helianthus annums), sorghum (Sorghum bicolor), pearl millet (Pennisetum glaucum), and buckwheat (Fagopyrum esculentum) were used as trap crops in an intercropping system outside of the high tunnel and open field plots (Frey, 2018). To increase stink bug predator and parasitoid populations within tomato plots, sweet alyssum (Lobularia maritima) was used as a refuge crop. The effectiveness of these crops in their respective roles was reported by Gordon (2016).

Plant growth measurements. Stem diameter and plant height were measured throughout the growing season, while aboveground biomass was sampled after the final harvest (13 July 2016 and 7 July 2017). Four representative plants from each subsubplot were chosen one month after transplanting for stem diameter and height measurements, and these same plants were used for aboveground biomass measurement after the final harvest. Tomato stem diameter was measured with a digital caliper at $3 \mathrm{~cm}$ aboveground level, assuring the measurement was taken above the grafting union for grafted plants. Tomato height was measured from ground level to the highest growing tip. In 2016, plant biometric parameters were measured on 1,15 , and 29 Apr., and 13 and 26 May for open field and high tunnel plots $(23,37$, 51,65 , and $78 \mathrm{~d}$ after transplanting, respectively), while high tunnel measurements continued after the open field final harvest with additional measurements on 13 and 29 June (96 and $112 \mathrm{~d}$ after transplanting, respectively). In 2017, plant biometric measurements took place on 14 and 28 Apr., 26 May, and 23 June (22, 36, 64 , and $92 \mathrm{~d}$ after the effective transplanting date).

Plant height and stem diameter measurements were reported as area under the plant height progress curve (AUPHPC) and area under the stem diameter progress curve (AUSDPC), respectively. The area under the growth progress curve (e.g., using plant height as a plant growth parameter) was analogous to the area under the disease progress curve (Fernandes et al., 2018). Results were presented in this manner to quantify not simply the height, but the height as a function of time, as early season vigor not only affects plant biological processes at the time of measurement, but also has a cumulative effect. The areas under the plant height and stem diameter progress curves (AUPHPC and AUSDPC, respectively) were calculated as follows:

$$
A U_{-} P C=\sum_{i=1}^{n} \frac{\left(x_{i}+x_{i-1}\right)}{2} \times\left(t_{i}-t_{i-1}\right),
$$

where $x_{i}=$ height or stem diameter measurement at $i^{\text {th }}$ observation; $t_{i}=$ time at $i^{\text {th }}$ observation; $n=$ number of observations. In this study, $i=0$ was the initial transplanting date, and a relative height and stem diameter of 0 was used for all treatments. This was because any differences at the transplanting stage were considered to be negligible.

Tomato YIELD MEASUREMENTS. Fruit were harvested twice each week at pink, light red, and red ripeness stages, as these are the stages targeted by direct-market growers. In 2016, harvest commenced on 29 Apr. and finished on 14 June and 6 July for the open field and high tunnel production systems, respectively. In 2017, harvest commenced on 18 May and finished on 3 July and 7 July for the open field and high tunnel production systems, respectively. For 'Tribute', the USDA tomato color classification standards were used to determine ripeness stage (USDA, 1991). For 'Garden Gem', a ripeness stage chart was developed for this research as this unique tomato cultivar does not ripen from blossom end to stem end but instead ripens uniformly across the entire fruit (Frey, 2018). All fruit were weighed and counted at each harvest. Marketable yield was determined by grading harvested fruit based on the following categories: marketable, decay, cracking, sunscald, BER, yellow shoulder disorder (YSD), stink bug damage, caterpillar (Lepidoptera) damage, and 
"other defects" (including small fruit, fruit that were grossly misshapen, or fruit with virus symptoms). In 2017 , a separate undersized category was added (whereas in 2016 undersized was included in the "other defects" category). This category was designated for fruit that had no other defects, and was used for 'Tribute' fruit less than $125 \mathrm{~g}$ and 'Garden Gem' fruit less than $35 \mathrm{~g}$. Fruit were assigned to a single unmarketable category in 2016 based on the predominant characteristic that made it unmarketable, while in 2017, procedures were adjusted to enable a single fruit to be assigned to as many categories as would, on their own, make the fruit unmarketable. This change only affected fruit categorized as unmarketable due to stink bug damage. Total yield was calculated as the sum of marketable and unmarketable fruit yield on a per plant basis. In 2016, marketable yield was determined on a per plant basis by grading all fruit harvested from every plant in each sub-subplot (four beds), whereas in 2017, subsamples of two beds in each sub-subplot were used to reduce labor requirements of fruit grading. Total yield was still measured for the entire sub-subplot and marketable yield per plant was then calculated for each treatment based on the percentage of marketable fruit from the harvest units. The average marketable fruit weight was calculated by dividing the marketable yield by the number of marketable fruit.

Statistical analyses. Given the different growing conditions between the two seasons, data analyses were performed for each season separately, following a linear mixed model using the GLIMMIX procedure of SAS (version 9.4; SAS Institute, Cary, NC). Normality, homogeneity of variances, and linearity were tested, and data were transformed logarithmically when needed. All results were presented with the original data. Multiple comparisons among different treatments were conducted using Fisher's least significant difference test $(\alpha=0.05)$.

\section{Results and discussion}

$P$ L A N T B I O M E T R I C MEASUREMENTS. High tunnel and grafting increased AUPHPC in 2016 by $93.0 \%$ and $7.0 \%$, respectively (Fig. 1A). Although no significant
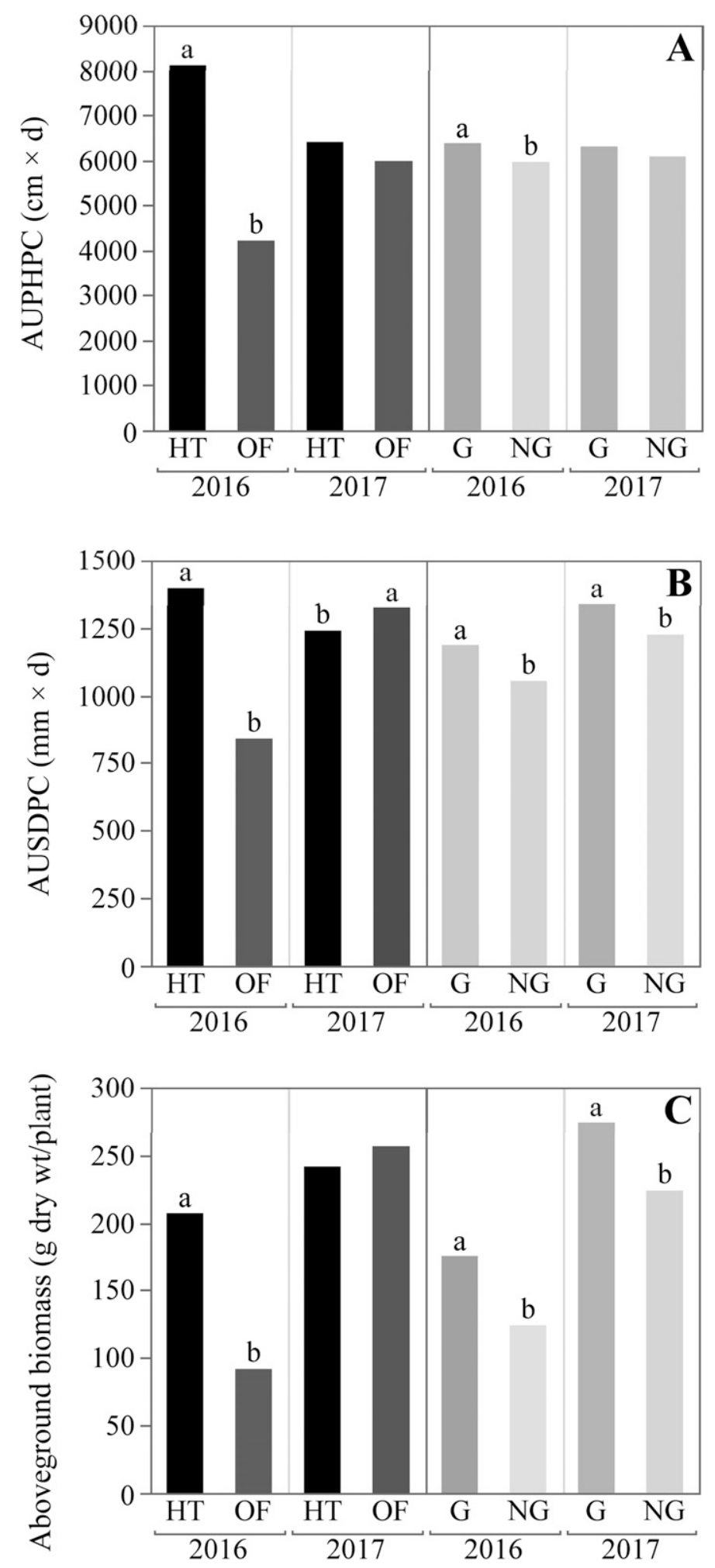

Fig. 1. Area under the plant height progress curve (AUPHPC), area under the stem diameter progress curve (AUSDPC), and end-of-season aboveground biomass as affected by production system and grafting in Spring 2016 and 2017 seasons in Citra, FL (HT = high tunnel, OF = open field, G = grafted, NG = nongrafted). Treatment analyses were separated by season, and letters that are the same within a season indicate the treatments are not significantly different $P \leq 0.05$ according to Fisher's least significant difference test. (A) AUPHPC as affected by production system and grafting. (B) AUSDPC as affected production system and grafting. (C) Aboveground biomass as affected by production system and grafting; $1 \mathrm{~cm}=0.3937 \mathrm{inch}, 1 \mathrm{~mm}=0.0394$ inch, $1 \mathrm{~g}=0.0353 \mathrm{oz}$. 

ments in 2017, increases by high tunnels, 'Garden Gem', and grafting were trending with probability values of $0.095,0.078$, and 0.074 , respectively (Table 1 ), resulting in relative AUPHPC increases of $7.2 \%, 4.8 \%$, and $3.9 \%$, respectively. High tunnels and grafting also significantly increased AUPHPC at the end of the 2016 open field season, by $11.6 \%$ and $4.8 \%$, respectively (data not shown). This corresponds much more closely with the increases identified in 2017. The magnitude of production system differences was greater than the magnitude of grafting differences in both seasons, indicating high tunnels had a greater impact on plant height than grafting. Significant increases in plant height in high tunnel vs. open field comparisons have also been previously reported (Rogers and Wszelaki, 2012), although this may not be due to an increase in plant vigor but rather the shading effect of the high tunnels.

The AUSDPC measurements indicated significant effects of production system, cultivar, and grafting in both seasons (Table 1). High tunnels increased AUSDPC by $66.7 \%$ over open field production in 2016 (Fig. 1B), yet no significant difference at the end of the open field production season (data not shown) indicated that the end-of-season results were exclusively dependent on the season extension achieved by the high tunnel system. In 2017, the AUSDPC in the differences were found among treat-

high tunnels was $6.4 \%$ lower than in the open field, possibly due to the late crop establishment and herbicide issues previously mentioned. Grafting increased AUSDPC by $12.2 \%$ and $9.3 \%$ in 2016 and 2017 , respectively, which is consistent with previous reports on stem diameter measurements (Öztekin and Tüzel, 2017; Rahmatian et al., 2014), indicating the impact of vigorous rootstocks on stem diameter. Significant cultivar and grafting effects on AUSDPC values were also observed at the end of the open field season in 2016, confirming that the results were treatment effects and not dependent upon season extension.

High tunnel aboveground biomass (dry weight) was $126 \%$ greater than in the open field at the end of the 2016 season (Fig. 1C), primarily due to extensive defoliation from foliar disease (early blight) in the open field (Frey et al., 2020). However, there was a lack of production system difference in 2017 (Table 1), possibly owing to the lower foliar disease severity that year. Cultivar differences only occurred in 2017, when 'Garden Gem' aboveground biomass was $12.4 \%$ greater than 'Tribute'. Grafting increased aboveground biomass by $41.5 \%$ and $22.5 \%$ in 2016 and 2017 , respectively. The biomass increase in grafted plants is consistent with previous findings, in which vigorous interspecific hybrid tomato rootstocks were used to promote

Table 1. Effects of production system, grafting, and tomato cultivar on plant growth measurements.

\begin{tabular}{|c|c|c|c|c|c|c|}
\hline \multirow[b]{2}{*}{ Factor $^{\mathrm{z}}$} & \multicolumn{2}{|c|}{ AUPHPC } & \multicolumn{2}{|c|}{ AUSDPC $^{\mathrm{x}}$} & \multicolumn{2}{|c|}{$\begin{array}{c}\text { Aboveground } \\
\text { biomass }^{w}\end{array}$} \\
\hline & $2016^{v}$ & 2017 & $2016^{v}$ & 2017 & 2016 & 2017 \\
\hline PS & $* * *$ & 0.095 & $* * *$ & $* * *$ & ** & NS \\
\hline $\mathrm{C}$ & NS & 0.078 & * & $* * *$ & NS & * \\
\hline G & ** & 0.074 & $* * *$ & $* * *$ & $* * *$ & $* * *$ \\
\hline $\mathrm{PS} \times \mathrm{C}$ & NS & NS & NS & NS & NS & NS \\
\hline $\mathrm{PS} \times \mathrm{G}$ & NS & NS & NS & NS & NS & NS \\
\hline $\mathrm{C} \times \mathrm{G}$ & NS & NS & NS & NS & NS & NS \\
\hline $\mathrm{PS} \times \mathrm{C} \times \mathrm{G}$ & NS & NS & NS & NS & NS & NS \\
\hline
\end{tabular}

${ }^{\mathrm{z}} \mathrm{PS}=$ production system (i.e., high tunnel vs. open field), $\mathrm{C}=$ cultivar, $\mathrm{G}=$ grafting. $\mathrm{NS},{ }^{*}, * *$, *** Nonsignificant or significant at $P \leq 0.05,0.01$, or 0.001 , respectively. Actual probability values are given if $P \leq 0.10$ to show data trends.

$\mathrm{y}_{\mathrm{AUPHPC}}=$ area under the plant height progress curve (centimeters $\times$ days). In 2016 , measurements occurred on 1, 15, and 29 Apr. and 13 and 26 May for open field and high tunnel plots, whereas high tunnel measurements continued after the open field final harvest with additional measurements on 13 and 29 June. In 2017, measurements occurred on 14 and 28 Apr., 26 May, and 23 June.

${ }^{\mathrm{x}} \mathrm{AUSDPC}=$ area under the stem diameter progress curve (millimeters $\times$ days). In 2016, measurements occurred on 1,15 , and 29 Apr. and 13 and 26 May for open field and high tunnel plots, while high tunnel measurements continued after the open field final harvest with additional measurements on 13 and 29 June. In 2017, measurements occurred on 14 and 28 Apr., 26 May, and 23 June.

wAboveground biomass was measured as dry weight per plant and occurred on 13 July 2016 and 7 July 2017.

${ }^{\vee}$ Data were logarithmically transformed to satisfy statistical assumptions. plant growth (Barrett et al., 2012; Rahmatian et al., 2014).

In this study, the increase of plant height, stem diameter, and aboveground biomass illustrated the increase of plant vigor induced by grafting onto 'Multifort', which was more consistent than scion cultivar and production system effects. The results can likely be attributed to a combination of the increased vigor from using the interspecific hybrid rootstock and the significant decrease in RKN soil population counts and root galling incidence and severity with grafted plants (Frey et al., 2020).

Total YIELD. Treatment effects on tomato yield varied with production seasons, which differed in environmental conditions and foliar disease severity (Frey et al., 2020). The 2016 high tunnel and open field harvest season lengths differed by $22 \mathrm{~d}$ (concluding 119 vs. $97 \mathrm{~d}$ after transplanting, respectively) due to early rains and the resulting high disease severity in the open field, while the 2017 high tunnel and open field harvests ended within $4 \mathrm{~d}$ of one another (106 vs. $102 \mathrm{~d}$ after the effective transplanting date) as open field disease severity was relatively low (Frey et al., 2020).

High tunnel yield was greater than open field yield in 2016 (Fig. $2 \mathrm{~A})$, at 5.88 and $4.11 \mathrm{~kg}$ per plant, respectively, yet in 2017 the yields were not significantly different. The total number of fruit per plant reflected this trend (Fig. 2B), with higher fruit counts in the high tunnel system than the open field in 2016 (89.3 and 61.8 fruit per plant, respectively, averaged over two cultivars), yet no significant differences being found in 2017 (at 80.6 and 83.9 fruit per plant, respectively, averaged over two cultivars). High tunnel effects on yield were congruent with plant biometric results, which is expected, as protected tomato yield predictive models using tomato plant biomass have been developed due to the impact of plant biomass on photosynthetic rate and resultant productivity (Chen et al., 2012). The primary factor affecting yield in the present study was the impact of disease severity on season extension. Studies by Healy et al. (2017) also showed that in seasons of high disease severity, disease reduction by high tunnels minimizes 

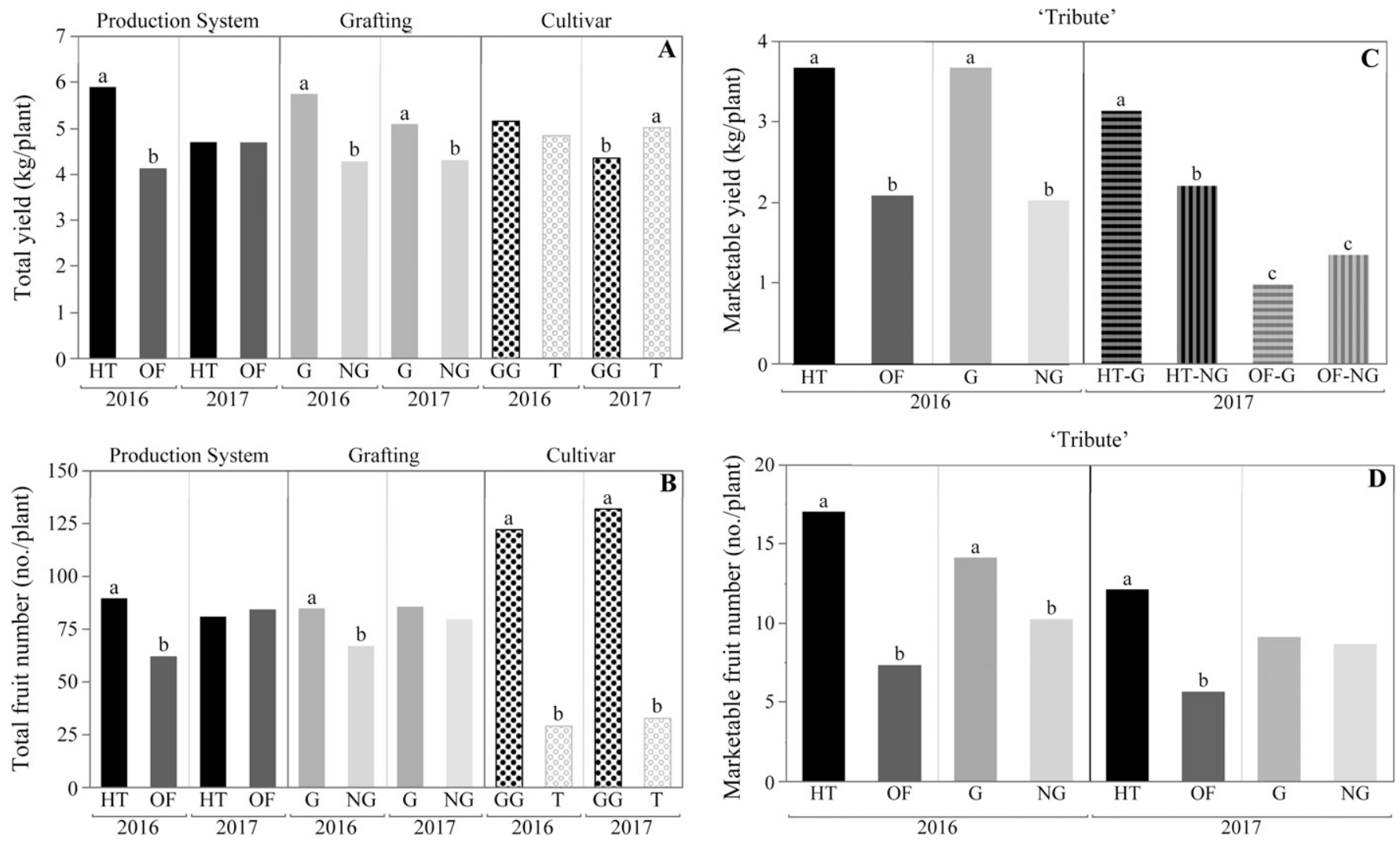

Fig. 2. Tomato yield components as affected by production system, grafting, and cultivar in Spring 2016 and 2017 production seasons (HT = high tunnel, OF = open field, G = grafted, NG = nongrafted, GG = 'Garden Gem', T = 'Tribute'). Treatment analyses were separated by season, and letters that are the same within a season indicate the treatments are not significantly different $P \leq \mathbf{0 . 0 5}$ according to Fisher's least significant difference test. Bars with mixed patterns are used to differentiate twoway interactions. (A) Total yield as affected by production system, grafting, and cultivar. (B) Total fruit number per plant as affected by production system, grafting, and cultivar. (C) 'Tribute' marketable yield as affected by production system and grafting. (D) 'Tribute' marketable fruit number per plant as affected by production system and grafting. 'Garden Gem' marketable yield results followed the same trends as 'Tribute' in 2016, while treatment effects were not significantly different in 2017; $1 \mathrm{~kg}=2.2046 \mathrm{lb}$.

disease effects on plant productivity and therefore increases yields. Yet in seasons with low disease severity, increases in high tunnel yields were primarily due to season extension, not relative increases in plant productivity.

Grafting significantly increased total yield by $34.3 \%$ and $18.2 \%$ in 2016 and 2017, respectively. Grafting also increased the total number of fruit per plant in both seasons, by $26.8 \%$ and $7.7 \%$ in 2016 and 2017 , respectively, although the latter was not significantly different (Table 2). Grafting effects on yield were also consistent with plant biometric results, and the potential increase in total yield and total fruit number with appropriate rootstock/scion selection has been widely reported (Djidonou et al., 2013; Rahmatian et al., 2014; Rivard et al., 2010; Turhan et al., 2011).
While not significantly different, 2016 'Garden Gem' total yields trended higher than 'Tribute' $(P=$ 0.096 ), at 5.15 vs. $4.84 \mathrm{~kg}$ per plant, respectively (Fig. 2A). However, in 2017 the reverse was found, as 'Tribute' total yields were significantly greater than 'Garden Gem', at 5.01 vs. $4.35 \mathrm{~kg}$ per plant, respectively. This was likely due to the smaller size of 'Garden Gem' fruit as 'Garden Gem' average marketable fruit weight (AMFW) was lower in 2017 by $17 \%$ compared with the 2016 season, whereas 'Tribute' AMFW was 0.9\% greater in 2017. The percentage of unmarketable fruit categorized as 'undersized' was also greater for 'Garden Gem'. As expected, total fruit number was significantly greater for 'Garden Gem' in both seasons due to the difference in tomato types.

Marketable yield. Production system and grafting main effects were observed on marketable yield across both cultivars in 2016 (Table 2). Marketable yield increased with high tunnels and grafting by $87.1 \%$ and $42.3 \%$, respectively (Fig. 2C). The number of marketable fruit per plant also increased with high tunnel production and grafting, by $83.8 \%$ and $32.7 \%$, respectively (Fig. 2D). Marketable yield was not significantly different between cultivars, while genetic differences resulted in a greater number of marketable fruit for 'Garden Gem' compared with 'Tribute', at 61.1 and 12.2 marketable fruit per plant, respectively. In addition, both production system and grafting had two-way interactions with cultivar (Table 2), with 'Tribute' benefiting from both high tunnel and grafting more than 'Garden Gem' in terms of marketable yield (data not shown). Marketable yield of 'Tribute' increased $32.8 \%$ more under high 
Table 2. Effects of production system, grafting, and tomato cultivar on fruit yield components (on a per plant basis).

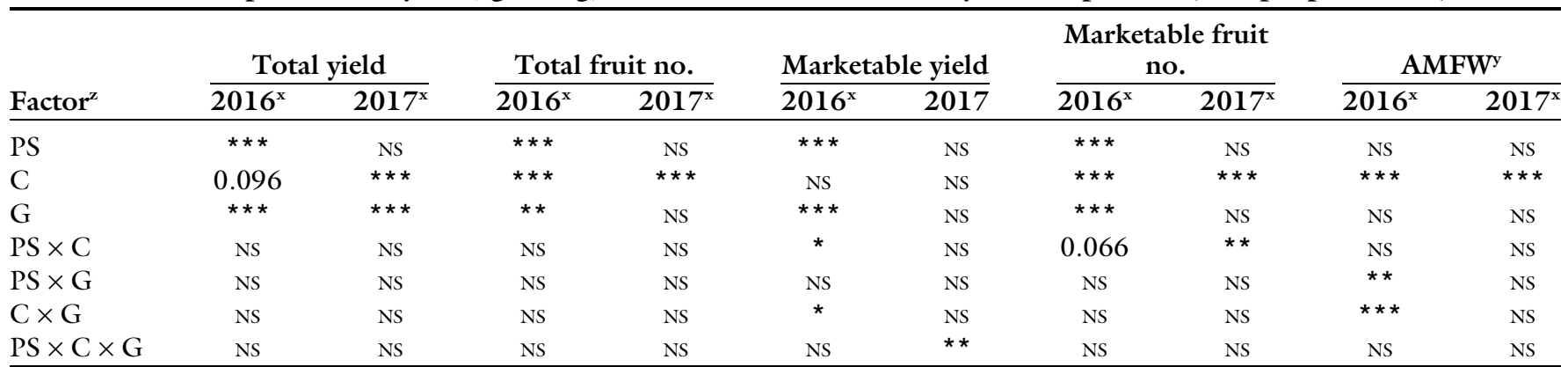

${ }^{\mathrm{z}} \mathrm{PS}=$ production system (i.e., high tunnel vs. open field), $\mathrm{C}=$ cultivar, $\mathrm{G}=$ grafting. Ns, ${ }^{*}, * *$, ***Nonsignificant or significant at $P \leq 0.05,0.01$, or 0.001 , respectively. Actual probability values are given if $P \leq 0.10$ to show data trends.

${ }^{\mathrm{y}} \mathrm{AMFW}=$ average marketable fruit weight.

${ }^{x}$ Data were logarithmically transformed to satisfy statistical assumptions.

tunnel production than for 'Garden Gem', while grafting increased marketable yield $44.6 \%$ more for 'Tribute' than 'Garden Gem'.

In 2017, none of the treatment main effects were found to significantly affect marketable yield, while there was a significant three-way interaction contributed by the impacts of production system and grafting on 'Tribute', with a lack of effects on 'Garden Gem' (Table 2; Fig. 2C). High tunnel 'Tribute' production significantly increased marketable yield, by $129 \%$ compared with the open field, and was congruent with 2016 results, while grafting increased the marketable yield of 'Tribute' in the high tunnel production system (by $42.1 \%$ ) but not in the open field. The number of marketable fruit per plant was significantly greater in 'Tribute' high tunnel production compared with the open field (115\%), whereas grafting did not affect the number of marketable fruit per plant (Fig. 2D).

Previous studies have demonstrated the overall benefits of using high tunnels to increase tomato marketable fruit number and yield, although those effects are season and cultivar dependent (Healy et al., 2017; Martin, 2013; O'Connell et al., 2012; Rogers and Wszelaki, 2012). Grafting has the potential to increase marketable fruit yield components (Djidonou et al., 2013), yet results may depend on rootstock/ scion selection and seasonal environmental conditions (Barrett et al., 2012; Rivard et al., 2010). The greater grafting benefit in a high tunnel production system compared with the open field for 'Tribute' observed in this study in the 2017 season, as reflected by the production system $x$ grafting $\times$ cultivar interaction, deserves further studies over multiple seasons.

Average marketable fruit WEIGHT. In 2016, grafting increased 'Tribute' AMFW by $19.5 \%$ (from 195 to $233 \mathrm{~g}$ ), whereas no differences related to grafting were seen for 'Garden Gem'. Additionally, production system by grafting interactions were identified (Table 2), in which the AMFW for open field, grafted tomatoes was greater than all other treatments. These results were unexpected, yet further examination revealed that AMFW peaked early in the season, on 20 May for 'Garden Gem' and 27 May for 'Tribute', while at the same time grafting effects were drastically reduced after the 8 June harvest. It was therefore the shorter open field harvest season that led to the greater proportion of total marketable fruit harvested when fruit size peaked and the grafting effect was at its maximum, rather than any physiological effect on AMFW by the combination of open field and grafting treatments. In 2017, however, no grafting or production system effects on AMFW were found. These results are consistent with work from Djidonou et al. (2013), indicating that although grafting has the potential to increase AMFW, results are dependent on a combination of factors, including rootstock-scion interactions, water and nutrient management, and seasonal conditions.

U N M A R K E T A B L E FR U I T CHARACTERISTICS. Few reports have examined differences in unmarketable characteristics between open field and high tunnel production systems, and little information is available about the interaction of production system and grafting effects. The major pests identified in this study, which directly or indirectly impacted tomato marketability, were tobacco hornworm (Manduca sexta), brown stink bug (Euschistus servus), and southern green stink bug (Nezara viridula). Additionally, leaf-footed bugs (Leptoglossus phyllopus) were identified in abundance on the trap crop, yet did not have a significant presence on the tomato crop. The major disease identified was early blight, while low incidence of bacterial spot (Xanthomonas vesicatoria) was also confirmed by the University of Florida Plant Diagnostic Center.

Stink bug damage, decay, and cracking ranked as the three most prevalent causes of unmarketable fruit (measured as a percentage of total yield), and cultivar effects were identified for all three (Table 3 ). Although seasonal differences were not statistically analyzed, the mean percent of total yield that was unmarketable due to stink bug damage, decay, and cracking each increased from 2016 to 2017 (from $10.0 \%$ to $28.4 \%$, $12.2 \%$ to $16.6 \%$, and $5.5 \%$ to $10.8 \%$, respectively), and together these were the main causes in the difference in marketable yield between seasons.

The percentage of the total yield that was unmarketable due to stink bug damage was significantly greater for 'Garden Gem' than 'Tribute' in both 2016 (13.5\% and 6.5\%, respectively) and 2017 (33.9\% and $22.8 \%$, respectively) (Fig. 3A). Even with well-established trap crops and integrated pesticide applications based on weekly scouting (Frey, 2018), relatively high fruit losses due to stink bug damage occurred in both seasons. 


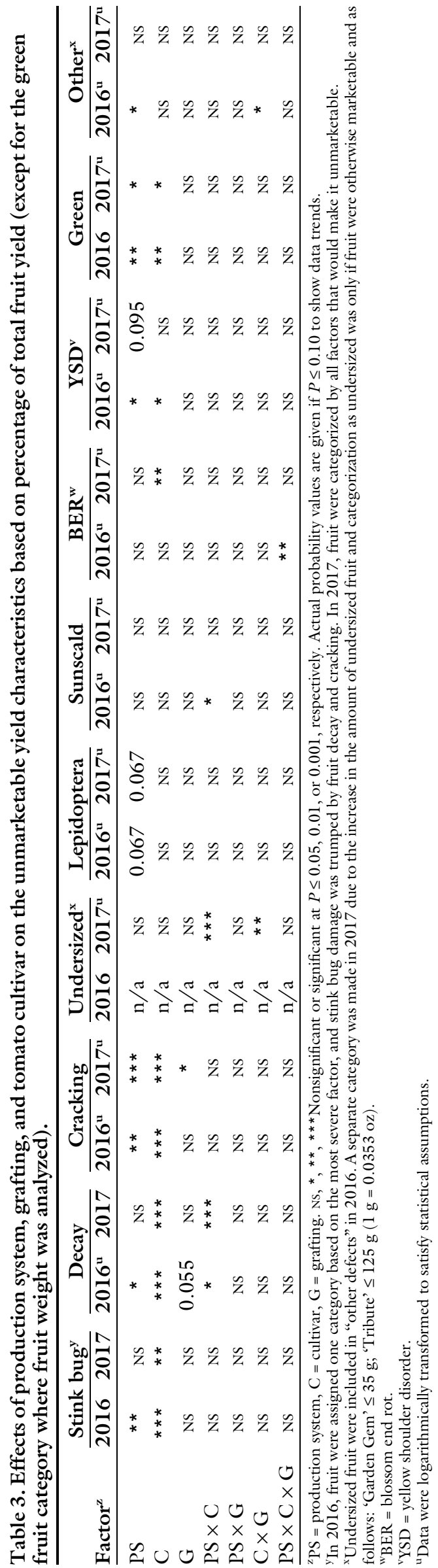

Stink bugs have increasingly become a major pest in organic tomato production because organic insecticides are largely ineffective (Kamminga et al., 2009; Morehead and Kuhar, 2017). The effectiveness of trap crops as used in this study was demonstrated in northern Florida tomato production by Gordon (2016); however, when implemented in this study, the trap crops did not lead to satisfactory results, implying greater host preference for one or both of the tomato cultivars than the trap crops. Maximizing the benefits of the high tunnel structure with the use of insect netting may be a promising alternative for stink bug management, although its effects on high tunnel microclimate conditions as well as tomato growth and yield must be monitored closely (Majumdar, 2015). Although stink bug occurrence was not recorded via stink bug counts within each treatment, the difference in percent of unmarketable fruit yield indicates cultivar preference by the pest, as previously found for the southern green stink bug (Grozea et al., 2012). Although the 2016 data indicate incidence of stink bug damage may be increased in high tunnel production, it is more likely that this was due to the categorization procedures used in 2016, as open field fruit with stink bug damage were more likely than high tunnel fruit to also have decay or cracking, and therefore be categorized as unmarketable due to either of the latter defects. The 2017 procedures adjusted for this, and no significant differences were found between production systems.

In this study, high tunnel production tended to reduce the proportion of the total yield that was unmarketable due to caterpillar damage in both seasons $[P=0.067$ (Table 3)]. The incidence of caterpillar damage was $4.2 \%$ in both seasons for open field and $1.7 \%$ in 2016 and $2.3 \%$ in 2017 for high tunnels. Overall, the caterpillar infestation level was low in this study, presumably due to the rotation of pesticide applications for stink bug management (Frey, 2018). Nevertheless, the effects of high tunnels on caterpillar damage in tomato production under subtropical conditions need to be further examined. 

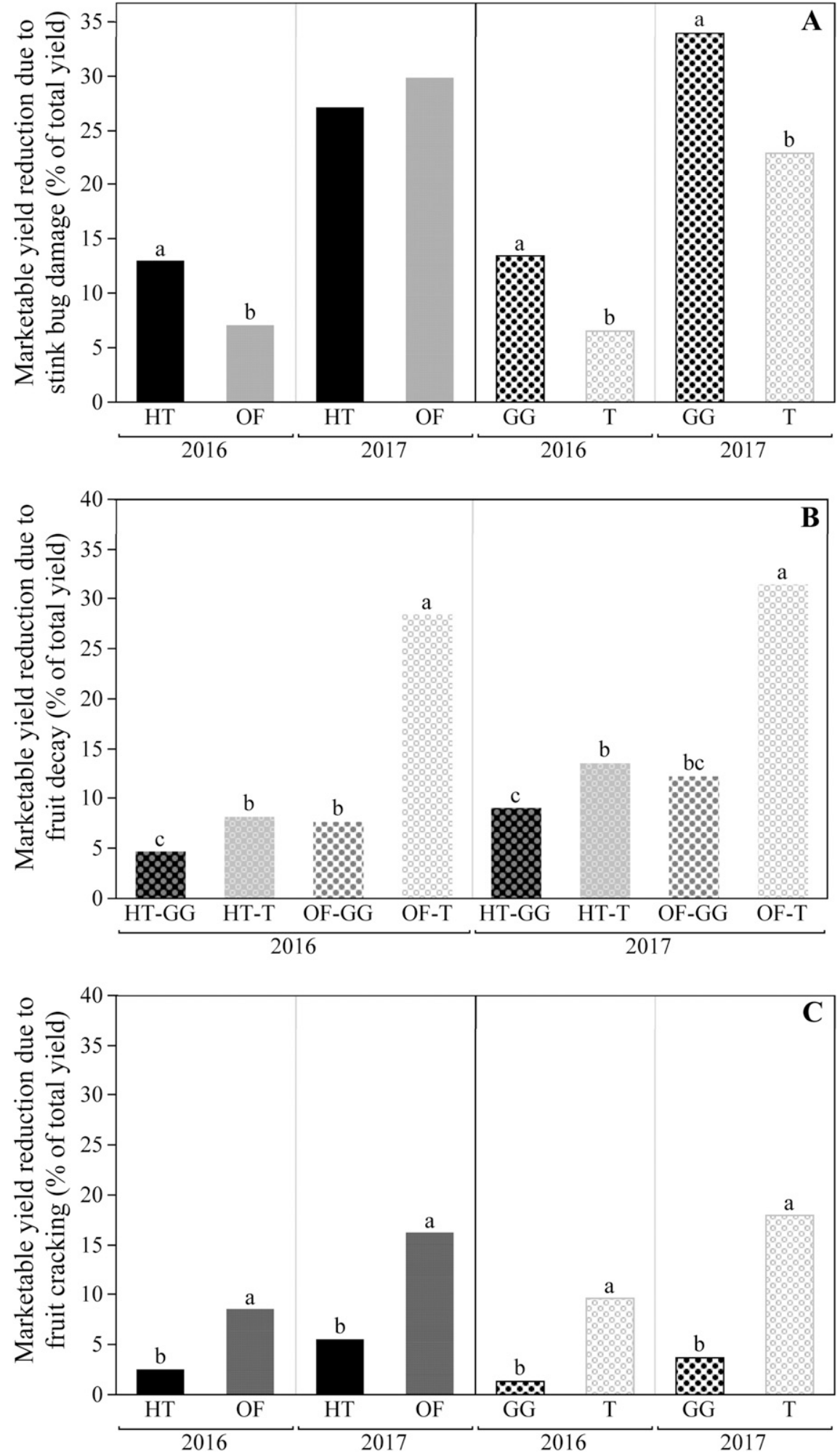

Fig. 3. Percent of total yield that is unmarketable due to stink bug damage, fruit decay and cracking as affected by production system and tomato cultivar in Spring 2016 and 2017 seasons $(\mathrm{HT}=$ high tunnel, $\mathrm{OF}=$ open field, GG = 'Garden Gem', T = 'Tribute'). Treatment analyses were separated by season, and letters that are the same within a season indicate the treatments are not significantly different at $P \leq 0.05$ according to Fisher's least significant difference test. Bars with mixed patterns are used to differentiate two-way interactions. (A) Marketable yield reduction due to stink bug damage as affected by production system and tomato cultivar. (B) Marketable yield reduction due to fruit decay as affected by production system and tomato cultivar. (C) Marketable yield reduction due to fruit cracking as affected by production system and tomato cultivar.
The percentage of total yield that was unmarketable due to decay was affected by production system and cultivar treatments (Table 3). The decay incidence was greater for 'Tribute' than 'Garden Gem' in both 2016 ( $18.3 \%$ and $6.2 \%$, respectively) and $2017(22.5 \%$ and $10.6 \%$, respectively) (Fig. 3B). In 2016, high tunnels reduced fruit decay by $64.4 \%$, from $18.1 \%$ in the open field to $6.4 \%$ in the high tunnel, and the high tunnel reduction of decay was greater for 'Tribute' $(71.3 \%)$ than for 'Garden Gem' $(38.9 \%)$. A production system by cultivar interaction occurred in 2017 as well, with high tunnels significantly reducing decay incidence for 'Tribute' (from $31.4 \%$ to $13.5 \%$ ), whereas 'Garden Gem' decay was unaffected.

The percentage of total yield that was unmarketable due to cracking was significantly greater for 'Tribute' than 'Garden Gem' in both 2016 (9.6\% and $1.3 \%$, respectively) and 2017 ( $17.9 \%$ and $3.7 \%$, respectively) (Fig. $3 \mathrm{C})$. High tunnel production reduced cracking by $71.1 \%$ in 2016 (from $8.5 \%$ to $2.5 \%$, respectively), and by $66.2 \%$ in 2017 (from 16.2\% to $5.5 \%$, respectively). Grafting effect was not observed in 2016, while cracking was increased from $9.5 \%$ for nongrafted treatments to $12.1 \%$ for grafted treatments in 2017. Multiple factors may affect fruit cracking, including cultivar susceptibility, fluctuations in plant water status and/or diurnal temperatures, high humidity, and high light intensity (Peet, 1992). The increase in cracking due to grafting identified in the 2017 season may be due to the enhanced water uptake that has been observed with the more vigorous root systems of selected rootstocks (Lee, 1994), whereas the reduction of cracking in the high tunnel system was most likely due to the consistency of soil water moisture that was observed throughout fruit development (data not shown). Previous research has suggested proper water management as the key to reducing tomato fruit cracking occurrence (O'Connell et al., 2012).

There was a noticeable increase in the occurrence of fruit that were undersized yet otherwise marketable from the onset of the 2017 harvest season, thus leading to the addition of undersized fruit as a separate category. The increased number of undersized 
fruit might be associated with the higher level of RKN infestation in 2017 compared with the 2016 season (Frey et al., 2020). While direct-market growers may not view all undersized fruit as unmarketable, it was determined to be important to quantify treatment effects. The cultivar by grafting interaction showed that grafting significantly reduced incidence of undersized fruit for 'Tribute', from $4.4 \%$ (nongrafted) to $1.8 \%$ (grafted), but it did not affect the undersized fruit incidence for 'Garden Gem'. Additionally, cultivar by production system interactions indicated similar values between production systems for 'Garden Gem', whereas undersized 'Tribute' fruit were more prevalent in high tunnel than in open field $(4.4 \%$ and $1.8 \%$, respectively). This higher incidence of undersized fruit for 'Tribute' in high tunnels may be largely attributed to the reduction of percent decay and percent cracking that was achieved with high tunnel production (Fig. $3 \mathrm{~B}$ and $\mathrm{C}$ ), with a greater proportion of small, ripening fruit in the open field succumbing to decay and therefore being categorized accordingly rather than as undersized.

The percentage of total yield that was unmarketable due to sunscald was reduced in the high tunnel for 'Garden Gem' ( $0.4 \%$ vs. 3.6\% for the open field) but not for 'Tribute' in 2016 (Table 3), whereas no treatment effects were observed in 2017. The high tunnel reduction in sunscald incidence in 2016 for 'Garden Gem' was likely due to the lower foliar disease severity compared with open field (Frey et al., 2020), which resulted in higher aboveground biomass at the end of the production season (Fig. 1C), providing greater foliar coverage for the fruit. The lack of difference in sunscald incidence in 2016 for 'Tribute' was most likely due to the high incidence of decay and cracking that occurred before sunscald development in those fruit, while the lack of difference in 2017 for both cultivars was most likely due to the lower open field foliar disease severity (Frey et al., 2020).

$\mathrm{BER}$ is a physiological disorder of tomato fruit that is now considered to be driven by abiotic stress conditions, including increased temperatures, relative humidity, and soil water fluctuations, resulting in an increase in reactive oxygen species that cause high oxidative stress, and finally cell death (Saure, 2014). Stress may interfere with calcium $\left(\mathrm{Ca}^{2+}\right)$ allocation or uptake by the fruit, making the observed low $\mathrm{Ca}^{2+}$ in symptomatic BER fruit a secondary consequence of the stress that causes the disorder (Saure, 2014). The production system $\times$ grafting $\times$ cultivar interaction found in 2016 showed that the percentage of total yield that was unmarketable due to BER was significantly higher for 'Tribute' high tunnel fruit $(5.7 \%)$ than for 'Tribute' open field fruit $(0.6 \%)$, while no significant difference was identified for 'Garden Gem'. Moreover, grafted 'Tribute' had significantly less BER in high tunnels, from $9.1 \%$ for nongrafted to $2.3 \%$ for grafted treatments (Table 3 ). The BER results in 2017 , however, only indicated cultivar effects, with BER incidence being significantly greater for 'Tribute' (1.5\%) than 'Garden Gem' (0.5\%). The potential for high tunnels to increase BER occurrence compared with open field systems, as well as cultivar differences in BER susceptibility, have previously been reported by Martin (2013). Although the high tunnel influence on BER was only observed in 2016 in the present study, future research is warranted to elucidate the potential impact of high tunnel environment on BER incidence and severity over multiple seasons. The potential for grafting to reduce BER has also been demonstrated previously (Fan et al., 2011; Krumbein and Schwarz, 2013), which indicates the importance for integrating grafting and high tunnel technologies to reduce potential negative high tunnel effects.

The percentage of total yield that was unmarketable due to the incidence of YSD was significantly greater in 2016 for 'Garden Gem' than 'Tribute' (at $3.5 \%$ and $1.7 \%$, respectively), while there were no cultivar effects in 2017. High tunnel production increased the YSD incidence in 2016 compared with the open field $(3.3 \%$ and $1.8 \%$, respectively), while production system differences in 2017 were trending at $P=0.095$ and the occurrence of YSD was much lower than the previous year $(0.7 \%$ for high tunnels and $0.3 \%$ for the open field, respectively). Production system effects on YSD were previously reported by Martin (2013), and were primarily linked to high temperature $\left(>33^{\circ} \mathrm{C}\right)$ during fruit development (Jett, 2004; Martin, 2013). The YSD results indicate another potential drawback of high tunnel production, although it is possible that cultivar selection may reduce the yield impact of this unmarketable trait.

Fruit harvested green was not a major marketability factor throughout the growing season, but rather is an indication of the relative amount of productivity remaining at the final harvest. For this reason, results were analyzed by total weight, and treatment differences are reported as a percent difference from one another. Fruit quality at final harvest was lacking due to high heat and stink bug damage, and this measurement of remaining green fruit is an indication of relative potential productivity if greater season extension could be achieved. The unmarketable fruit due to being green was $261 \%$ greater in the high tunnel than in the open field at final harvest in 2016, even while the high tunnel final harvest was $22 \mathrm{~d}$ after the open field final harvest (Table 3), and 40\% greater in 2017. The reduction in the magnitude of differences from 2016 to 2017 was likely due to the replanting that occurred in 2017 along with prolonged production in the open field (nearly matching the harvest season length of the high tunnel). This highlights the importance of achieving season extension for maximizing high tunnel benefits. The amount of green 'Garden Gem' fruit was also significantly greater than green 'Tribute' fruit, with $432 \%$ more fruit at final harvest in 2016, and 245\% more in 2017, indicating the critical role of cultivar selection in maximizing the harvest season in the high tunnels.

\section{Conclusions}

The two primary benefits of high tunnel tomato production were found to be the extension of the harvest period, thereby increasing total yields, and the reduction of fruit decay and cracking (and the potential to reduce insect damage), thereby increasing marketable yields. Season extension in subtropical summer months (such as found in Florida) may only be achieved when open field disease incidence and severity are high, and therefore early high tunnel 
planting should be the primary goal. Future research is needed to establish target high tunnel planting dates in subtropical climates to maximize season extension in each growing region; proper cultivar section and trellising management are also needed to maximize high tunnel benefits. Stink bug damage surpassed $28 \%$ of total fruit yields during the course of this study, clearly demonstrating that stink bug management is a major challenge in organic tomato production. Although a cost-effective solution in a high tunnel production system might be the utilization of insect screens to exclude the stink bugs, insect screen application may alter the high tunnel microclimate in ways that could reduce the benefits identified in this study. Future research is therefore needed to better manage high tunnel microclimate conditions when using pest barriers.

Grafting was shown to increase tomato plant vigor and productivity in terms of both total yield and fruit number. Combining grafting and high tunnel technologies demonstrated the potential to employ grafting advantages over a longer production season. Furthermore, grafting can reduce potential adverse effects of high tunnel conditions, including RKN incidence and severity (Frey et al., 2020) and fruit disorders, such as BER. Although grafting may increase fruit cracking, proper irrigation management may help reduce or eliminate this effect. Future research is warranted from a systems approach perspective, developing nutrient and irrigation management practices to maximize grafting and high tunnel benefits while minimizing potential detrimental effects.

\section{Literature cited}

Antignus, Y., N. Mor, R. Ben-Joseph, M. Lapidot, and S. Cohen. 1996. UV-absorbing plastic sheets protect crops from insect pests and from virus diseases vectored by insects. Environ. Entomol. 25:919-924.

Barrett, C.E., X. Zhao, and R. McSorley. 2012. Grafting for root-knot nematode control and yield improvement in organic heirloom tomato production. HortScience 47:614-620.

Blomgren, T. and T. Frisch. 2007. High tunnels: Using low-cost technology to increase yields, improve quality and sea- son extension. Univ. Vermont Ctr. Sustainable Agr., Burlington, VT.

Carey, E.E., L. Jett, W.J. Lamont, T.T. Nennich, M.D. Orzolek, and K.A. Williams. 2009. Horticultural crop production in high tunnels in the United States: A snapshot. HortTechnology 19:37-43.

Chen, Y., Z. Zhang, Y. Liu, Y. Zhu, and H. Cao. 2012. Models of dry matter production and yield formation for the protected tomato, p. 278-292. In: D. Li and Y. Chen (eds.). Computer and computing technologies in agriculture $\mathrm{V}$. CCTA 2011. IFIP Advances in Information and Communication Technology. Vol. 368. Springer, Berlin, Germany.

Di Gioia, F., A. Signore, F. Serio, and P. Santamaria. 2013. Grafting improves tomato salinity tolerance through sodium partitioning within the shoot. HortScience 48:855-862.

Djidonou, D., X. Zhao, E.H. Simonne, K.E. Koch, and J.E. Erickson. 2013. Yield, water-, and nitrogen-use efficiency in field-grown, grafted tomatoes. Hort Science 48:485-492.

Fan, M., Z. Bie, A. Krumbein, and D. Schwarz. 2011. Salinity stress in tomatoes can be alleviated by grafting and potassium depending on the rootstock and Kconcentration employed. Scientia Hort. 130:615-623.

Fernandes, S.B., K.O.G. Dias, D.F. Ferreira, and P.J. Brown. 2018. Efficiency of multi-trait, indirect, and trait-assisted genomic selection for improvement of biomass sorghum. Theor. Appl. Genet. 131:747-755.

Frey, C. 2018. Sustainable organic tomato production in subtropical Florida: High tunnel and grafting effects on production and postharvest qualities. MS Thesis, Univ. Florida, Gainesville.

Frey, C.J., X. Zhao, J.K. Brecht, D.M. Huff, and Z.E. Black. 2020. High tunnel and grafting effects on organic tomato plant disease severity and root-knot nematode infestation in a subtropical climate with sandy soils. HortScience 55:46-54.

Gordon, T.L. 2016. Integrated pest management of the southern green stink bug, Nezara viridula (Hemiptera: Pentatomidae), on tomato crop in north Florida. MS Thesis, Florida Agr. Mechanical Univ., Tallahassee.

Grozea, I., R. Ştef, A.M. Virteiu, A. Cărăbeţ, and L. Molnar. 2012. Southern green stink bugs (Nezara viridula L.) a new pest of tomato crops in western Romania. Res. J. Agr. Sci. 44:24-27.

Guan, W., X. Zhao, R. Hassel, and J. Thies. 2012. Defense mechanisms in- volved in disease resistance of grafted vegetables. HortScience 47:164-170.

Healy, G.K., B.J. Emerson, and J.C. Dawson. 2017. Tomato variety trials for productivity and quality in organic hoop house versus open field management. Renew. Agr. Food Syst. 32:562-572.

Hochmuth, R.C. and D.E. Toro. 2014. Characterization of the Florida fresh fruit and vegetable industry using hydroponic systems or protected agriculture structures. Univ. Florida IFAS EDIS Publ. HS1240. 1 Nov. 2019. <http://edis.ifas. ufl.edu/hs1240>.

Janke, R.R., M.E. Altamimi, and M. Khan. 2017. The use of high tunnels to produce fruit and vegetable crops in North America. Agr. Sci. 8:692-715.

Jayalath, T.C., G.E. Boyhan, E.L. Little, R.I. Tate, and S. O'Connell. 2017. High tunnel and field system comparison for spring organic lettuce production in Georgia. HortScience 52:1518-1524.

Jett, L.W. 2004. High tunnel tomato production. 1 Nov. 2019. <https://mospace. umsystem.edu/xmlui/bitstream/handle/ $10355 / 51733 / \mathrm{m0170-2004.pdf?}$ sequence $=1>$.

Kamminga, K.L., D.A. Herbert, Jr., T.P. Kuhar, S. Malone, and H. Doughty. 2009. Toxicity, feeding preference, and repellency associated with selected organic insecticides against Acrosternum hilare, and Euschistus servus (Hemiptera: Pentatomidae). J. Econ. Entomol. 102:19151921.

King, S.R., A.R. Davis, W. Liu, and A. Levi. 2008. Grafting for disease resistance. HortScience 43:1673-1676.

Krumbein, A. and D. Schwarz. 2013. Grafting: A possibility to enhance health promoting and flavour compounds in tomato fruits of shaded plants? Scientia Hort. 149:97-107.

Lamont, W.J., Jr. 2005. Plastics: Modifying the microclimate for the production of vegetable crops. HortTechnology 15:477-481.

Lamont, W.J., Jr. 2009. Overview of the use of high tunnels worldwide. HortTechnology 19:25-29.

Leach, H., J.C. Wise, and R. Isaacs. 2017. Reduced ultraviolet light transmission increases insecticide longevity in protected culture raspberry production. Chemosphere 189:454-465.

Lee, J.-M. 1994. Cultivation of grafted vegetables. I. Current status, grafting methods, and benefits. HortScience 29:235-239. 
Liu, G., E.H. Simonne, K.T. Morgan, G.J. Hochmuth, M. Ozores-Hampton, and S. Agehara. 2016. Chapter 2. Fertilizer management for vegetable production in Florida, p. 3-10. In: G.E. Vallad, H.A. Smith, P.J. Dittmar, and J.H. Freeman (eds.). Vegetable production handbook of Florida. 25 Oct. 2019. <https://swfrec.ifas.ufl.edu/ docs/pdf/veg-hort/veg-prod-guide/ 2016-17-veg-prod-guide.pdf>.

Majumdar, A. 2015. High tunnel pest exclusion system: A novel strategy for organic crop production in the South. 25 Oct. 2019. <http://hightunnels.org/ high-tunnel-pest-exclusion-system-anovel-strategy-for-organic-cropproduction-in-the-south $/>$.

Martin, J.T. 2013. The influence of organically managed high tunnel and open field production systems on strawberry (Fragaria $\times$ ananassa) quality and yield, tomato (Solanum lycopersicum) yield, and evaluation of plastic mulch alternatives. MS Thesis, Univ. Tennessee, Knoxville.

McAvoy, G. and M. Ozores-Hampton. 2007. Unique challenges for Florida growers in tomato and pepper production. 6 Mar. 2020. <https://edis.ifas. ufl.edu/pdffiles/IN/IN73300.pdf>.

Morehead, J.A. and T.P. Kuhar. 2017. Efficacy of organically approved insecticides against brown marmorated stink bug, Halyomorpha halys, and other stink bugs. J. Pest Sci. 90:1277-1285.

O'Connell, S., C. Rivard, M.M. Peet, C. Harlow, and F. Louws. 2012. High tunnel and field production of organic heirloom tomatoes: Yield, fruit quality, disease, and microclimate. HortScience 47:1283-1290.

Öztekin, G.B. and Y. Tüzel. 2017. Grafted organic seedling production of tomato and watermelon. Acta Hort. 1164:69-75.

Peet, M.M. 1992. Fruit cracking in tomato. Hort Technology 2:216-223.

Rahmatian, A., M. Delshad, and R. Salehi. 2014. Effect of grafting on growth, yield and fruit quality of single and double stemmed tomato plants grown hydroponically. Hort. Environ. Biotechnol. 55:115-119.

Rivard, C.L., S. O'Connell, M.M. Peet, and F.J. Louws. 2010. Grafting tomato with interspecific rootstock to manage diseases caused by Sclerotium rolfsii and southern root-knot nematode. Plant Dis. 94:1015-1021.

Rivard, C.L., S. O'Connell, M.M. Peet, R.M. Welker, and F.J. Louws. 2012. Grafting tomato to manage bacterial wilt caused by Ralstonia solanacearum in the southeastern United States. Plant Dis. 96:973-978.

Rogers, M.A. and A.L. Wszelaki. 2012. Influence of high tunnel production and planting date on yield, growth, and early blight development on organically grown heirloom and hybrid tomato. HortTechnology 22:452-462.

Saure, M.C. 2014. Why calcium deficiency is not the cause of blossom-end rot in tomato and pepper fruit - A reappraisal. Scientia Hort. 174:151-154.

Savvas, D., A. Savva, G. Ntatsi, A. Ropokis, I. Karapanos, A. Krumbein, and C. Olympios. 2010. Effects of three commercial rootstocks on mineral nutrition, fruit yield, and quality of salinized tomato. J. Plant Nutr. Soil Sci. 174:154-162.

Seufert, V., N. Ramankutty, and J.A. Foley. 2012. Comparing the yields of organic and conventional agriculture. $\mathrm{Na}$ ture 485:229-232.

Shaner, D.L. 2014. Herbicide handbook. 10th ed. Weed Sci. Soc. Amer., Lawrence, KS.

Talavera-Bianchi, M., E. Chambers, IV., E.E. Carey, and D.H. Chambers. 2010. Effect of organic production and fertilizer variables on the sensory properties of pac choi (Brassica rapa var. Mei Qing Choi) and tomato (Solanum lycopersicum var. Bush Celebrity). J. Sci. Food Agr. 90:981-988.

Thaxton, B.R. and R.C. Hochmuth. 2019. Tomato cultivar selection considerations for open-field and protected culture in north Florida. 25 Oct. 2015. $<$ http://edis.ifas.ufl.edu/pdffiles/HS/ HS127300.pdf>.

Turhan, A., N. Ozmen, M.S. Serbeci, and V. Seniz. 2011. Effects of grafting on different rootstocks on tomato fruit yield and quality. Hort. Sci. (Prague) 38:142-149.

U.S. Department of Agriculture. 1991. United States standards for grades of fresh tomatoes. 15 Nov. 2019. <https://www. ams.usda.gov/sites/default/files/media/ Tomato_Standard\%5B1\%5D.pdf>.

U.S. Department of Agriculture. 2008. Farms, land use, and sales of organically produced commodities on certified and exempts organic farms: 2008. 15 Nov. 2019. <https://www.nass.usda.gov/ Publications/AgCensus/2007/Online_ Highlights/Organics/organics_1_0l.pdfs.

U.S. Department of Agriculture. 2015a. Organic farming: Results from the 2014 organic survey. 15 Nov. 2019. <https:// www.nass.usda.gov/Publications / Highlights/2015/2014_Organic_Survey_ Highlights.pdf $>$.

U.S. Department of Agriculture. 2015b. Table 22. Marketing practices - certified and exempt organic farms: 2014. 15 Nov. 2019. <https://www.nass.usda.gov/ Publications/AgCensus/2012/Online Resources/Organics/organics_1_022_ 022.pdf>.

U.S. Department of Agriculture. 2016. Data and statistics. 15 Nov. 2019. <https://www. nass.usda.gov/Data_and_Statistics/index. php>.

U.S. Department of Agriculture. 2017. Certified organic survey 2016 summary. 15 Nov. 2019. <https://downloads.usda. library.cornell.edu/usda-esmis/files/ zg64tk92g/70795b52w/4m90dz33q/ OrganicProduction-09-20-2017_ correction.pdf>.

Waiganjo, M., D. Omaiyo, C. Gathambiri, S. Kuria, C. Njeru, M. Kleinhenz, J. Kovach, S. Miller, and M. Erbaugh. 2013. Effects of grafting and high tunnel tomato production on pest incidence, yield and fruit quality in smallholder farms in central Kenya. East African Agr. For. J. 79:107-111

Zhu, Y., C.A. Sims, H.J. Klee, and P.J. Sarnoski. 2017. Sensory and flavor characteristics of tomato juice from Garden Gem and Roma tomatoes with comparison to commercial tomato juice. J. Food Sci. 83:153-161. 